adopted by the Senate, although a similar bill also was introduced in the Senate. ${ }^{66}$ It is likely that the present Congress will seriously consider the enactment of a reorganization statute covering municipal corporations. ${ }^{67}$ Such a statute presents serious questions of policy which cannot be considered here, but there can be no doubt as to the wisdom of including industrial corporations, which face precisely the same difficulties as the railroads in attempting to reorganize through equity receiverships.

\title{
THE COURTS AND COMMITTEE REPORTS
}

\section{J. P. Chamiberlain*}

$\mathrm{E}^{\mathrm{v}}$ VEN a cursory examination of the Supreme Court reports for the last few years will make evident the fact that the number of cases in which the courts are called upon to interpret and apply statutes is steadily increasing. In passing upon these cases the courts have universally declared that it is their duty to interpret acts in accordance with the intent of Congress, and not themselves to legislate. It is of great importance to business men, to members of the bar who advise them, and to administrative departments of the government which are making rules to carry out the will of Congress, that they should know the means which the court will use in determining such intent, and how far instruments other than the statute itself can be relied upon in the process of interpretation.

It is well settled that where the language of the law is clear and the construction according to its terms does not lead to absurd or impractical consequences, the words are to be taken as final, and nothing else can be resorted to in order to determine its meaning. ${ }^{\mathrm{S}}$

66 S. $555 \mathrm{I}$, introduced January Io, 1933 by Senator Hastings.

${ }^{67}$ In the corporate reorganization section of H.R. I4359, which, as stated above, was not adopted by the Senate, "drainage, irrigation, levee, sewer and paving improvement districts established under the laws of the State of their creation" were included along with industrial corporations. Senator Fletcher, on January 10, r933, introduced an amendment to H.R. 44359 embracing a reorganization section, modelled on the others, to cover "any municipality or other political subdivision of any State." The amendment was not adopted, but Senator Fletcher has introduced a similar bill (S. 403) in the present session of Congress, and a separate bill with the same object but differing in many respects from the Fletcher bill has been introduced in the House by Representative McLeod (H.R. 43II). It is likely that these bills will receive prompt consideration by the respective Judiciary Committees.

* Professor of Public Law, Columbia University.

× United States v. Missouri Pac. Ry. Co., 278 U.S. 269, 49 Sup. Ct. 133, 73 L.Ed. 322 (Ig28); Van Camp \& Sons v. American Can Co., 278 U.S. 245, 49 Sup. Ct. I12, 73 L.Ed. 3 II (I928); Work v. United States ex rel. Rives, 295 Fed. 225 (I924); Caminetti v. United States, 242 U.S. 470, 37 Sup. Ct. I92, 6r L.Ed. 442 (I917); Standard Fashion Co. v. McGrane Houston Co., 258 U.S. 346,42 Sup. Ct. 360 , 66 L.Ed. 653 (I921); Ozawa v. United States, 260 U.S. r 78 , 43 Sup. Ct. 65,67 L.Ed. 199 (I922); United States v. Shreveport Grain \& Elevator Co., 287 U.S. 77, 53 Sup. Ct. 42, 77 L.Ed. 94 (1932). 
If, however, the statute is either ambiguous or obscure, so that the intent of Congress would not be easy to gather solely from the words used, the court may depend on other evidence to establish its meaning, notably, the reports of committees of Congress and the statement of the chairman or other member of the committee who is in charge of the bill. ${ }^{2}$

In order to understand the connection between the activities of the committee and congressional intent, some knowledge of legislative procedure is necessary. When a bill is introduced into Congress it is immediately referred to one of the standing committees, and, except in rare cases, it does not reappear on the floor of Congress for passage until it has been carefully considered in that committee. Thus it is in the committees of Congress that the actual work is done of determining whether a situation exists which requires a remedy, what remedy should be applied, and what administrative devices should be used.

When submitting the bill to Congress it is customary for the committee to prepare and submit a report explaining the grounds for its action, the factual and legal bases upon which the statute rests, and the committee's understanding of the nature and effect of the bill. The hearings, and frequently briefs in support of or against the measure, together with explanatory memoranda prepared by the committee's counsel, are also printed and form part of the record before Congress.

When the bill is introduced it is customary for the member of the committee in charge of the bill, normally the chairman, to explain it in a speech, and afterward in debate to answer questions as to the meaning of particular sections or phrases in the bill. As the committeeman in charge has the burden of defending the bill he has familiarized himself with the situation to be dealt with, both as to fact and as to law, and his statements may be taken as the opinion of the committee as to what it meant by the bill as introduced. Where a bill passes, either unchanged as introduced by the committee or with few changes, it is fair to assume that Congress has adopted as its intent the intent of the committee, and that the documents setting forth the intent of the committee, including the speech and answers to questions made on the floor by the member in charge, may be consulted to ascertain the will of Congress. If in the course of the debate a change is made in the wording of the bill, either with the approval of the committee member in charge or at the suggestion of another member, the statement of the member suggesting the amendment is also authoritative as to his meaning.

Two cases will illustrate the use of a committee report to explain the meaning of phrases obscure only because of their context. The provision of the Clayton Act giving a person accused in certain contempt proceedings the right to trial by jury, used the word "may." In order to aid in determining whether the word "may" should be mandatory and not permissive, in other words, should practically be given the meaning "shall," the court referred to the report of the

${ }_{2}^{2}$ Duplex Printing Press v. Deering, 254 U.S. 443, 4r Sup. Ct. 172, 65 L.Ed. 349 (I920). 
Judiciary Committee of the House to the effect that trial is to be by the court in certain specified cases, but adds "in other cases the trial is to be by jury." Thus, said the court:

The intent of Congress in adopting the provision was to give to the accused a right of trial by jury; not merely to vest authority in the judge to call a jury at his discretion. 3

In determining whether the word "stayed," used in a section of the Revenue Act of 1928 , included a voluntary delay as well as a stay under a judicial order or by virtue of statute, the court made use of the committee reports and especially of the report of the House Committee where the phrase originated.4 In the lower courts there had been a division of opinion as to the meaning of the expression and also as to the propriety of using the committee reports. One court had remarked that it was unnecessary to quote the language of the report, as the word "stayed" must be given its plain meaning, 5 whereas other courts had used the committee report in deducing the rule which was finally approved by the Supreme Court. ${ }^{6}$

The question as to whether an act is so clear as to make it unnecessary to use a committee report in interpreting it, is far from easy to determine. For example, in a recent case a section of the Food and Drugs Act was involved, refusing shipment in interstate commerce to food or drugs:

Third. If in package form, the quantity of the contents be not plainly and conspicuously marked on the outside of the package in terms of weight, measure, or numerical count: Provided, however, That reasonable variations shall be permitted, and tolerances and also exemptions as to small packages shall be established by rules and regulations made in accordance with the provisions of section 3 of this Act. ${ }^{7}$

The point involved was whether rules and regulations could be made in respect to variations. The court decided that they could, and reached this result by adding a comma after the word "established." So punctuated, the court said, it was obvious that the provision as to rules and regulations would apply to the first clause relating to variations as well as to the second, relating to tolerances and exemptions. "Punctuation marks," said the court, "are no part of an act. To determine the intent of the law, the court, in construing a statute, will disregard the punctuation, or will repunctuate, if that be necessary, in order to arrive at the natural meaning of the words employed."

Inferentially the court admits that without the change in the punctuation,

${ }^{3}$ Michaelson v. United States ex rel. C. St. P., M. \& O. R. Co., 266 U.S. 42, 70, 45 Sup. Ct. I8, 69 L.Ed. I62, I69 (I924).

4 Graham v. Goodcell, 282 U.S. 409, 5 I Sup. Ct. 186 , 75 L.Ed. 4 r 5 (r930).

5 United States v. Burden, Smith \& Co., 33 F. (2d) 229 (rg29).

${ }^{6}$ Regla Coal Co. v. Bowers, 37 F. (2d) 373 (S.D. N.Y. 1929).

7 United States v. Shreveport Grain and Elevator Co., 287 U.S. 77, 53 Sup. Ct. 42, 77 I.Ed. 94 ( 1932$)$.

${ }^{73}$ Ibid., p. 82. 
it would be hard to construe the clause authorizing rules and regulations, as applying to the proviso "that reasonable variations shall be permitted.". Without the comma added, the meaning would seem clearly contrary to the meaning which the court was forced to justify by adding a comma. This then would seem to have been a case of doubt in which the court, according to its own rule, should have given due regard to the committee report, which "agreed with the view that the authority to make rules and regulations was confined to the establishment of tolerances and exemptions," in other words, did not apply to "reasonable variations." In concurring, Justices Brandeis, Stone and Cardozo remarked that "the statute, as punctuated, reads as its legislative history shows Congress intended it to read."

In this case the statute could have been made perfectly clear by reference to the committee report, but there was another means of interpretation which was given greater weight by the majority of the court. The executive department charged with the administration of the act had from the beginning adopted the interpretation accepted by the majority of the court, and had incorporated it into its rules and regulations. Apparently the court was unwilling to modify the long-continued administrative practice, to which, as it remarked, no objection had been made by Congress, and in fact preferred to disregard the will of Congress at the time of the passage of the act, as shown by the committee report, rather than to disregard the long-continued practice of the administration.

The court has taken a realistic view of the procedure in Congress by singling out from the general debate on a bill, the statements made by a member of the committee in charge of the bill on the floor. Such speeches may be regarded as authorized statements by the agent of the committee of what its intention was, and where there is doubt as to the meaning of the words of the act, may be considered as having been taken by the members of the House or Senate as authoritative, and therefore as expressing their will. The court has well expressed this point of view in its opinion in the case of the Duplex Printing Press v. Deering: 9

This was the final work of the House committee on the subject, and was uttered under such circumstances and with such impressive emphasis that it is not going too far to say that, except for this exposition of the meaning of the section (Clayton Act, §20), it would not have been enacted in the form in which it was reported. In substantially that form it became law; and since, in our opinion, its proper construction is entirely in accord with its purpose as thus declared, little need be added.

In the case at bar the statement of the committee chairman was made in answer to a question by another member who suggested an amendment to the bill, which was opposed by the chairman on the ground that the bill as it was drafted covered the point which was contained in the amendment, and that, therefore, the amendment was unnecessary. ${ }^{10}$

\footnotetext{
${ }^{8}$ Ibid., p. $45 . \quad 9254$ U.S. $443,477,4$ I Sup. Ct. I72, 65 L.Ed. 349 (I920).

${ }^{10}$ Binns v. United States, 194 U.S. 486 , 24 Sup. Ct. 8I6, 48 L.Ed. ro8 7 (r903).
} 
In another case the court depended on the amendment offered by the member in charge of a bill to take care of an objection urged by another member during the debate, and his explanations of the amendment were taken into consideration as "throwing light upon the meaning of the proviso."

It is an interesting indication of the change in the attitude of the court toward statements of committee members to observe that in the opinion in United States v. Trans-Missouri Freight Association, ${ }^{\mathrm{r2}}$ the court refused to take into consideration the statement of Senator Hoar who, as a member of the committee on conference from the Senate, reported the conference bill to the Senate. ${ }^{33}$ The court, however, after a long and somewhat involved argument arrived at the conclusion that the bill meant exactly what Senator Hoar said it meant, so that, although it was not willing to admit that the members of Congress accepted Senator Hoar's interpretation of the meaning of the act, it found that the will of Congress was in fact the will of the committee as reported by its authorized representative on the floor.

In a more recent case, the court might have saved itself a considerable amount of trouble had it been willing to take the statement of the chairman of the Senate committee rather than reason about the meaning of a word. The Interstate Commerce Act applied to "railroads." The question at issue was whether street railroads were included in the term. The chairman of the Senate committee, in reporting the bill, had declared that the word "railroads" did not cover street railroads. The court, failing to appreciate the difference which the Duplex case made clear between general debate and the statements of the chairman, refused to consider his statements as other than part of the debate, and then went on to find out in another manner that Congress meant what the chairman said it meant. It $^{4}$ It is obvious that the court has grown in understanding of the ways of Congress; and without an understanding of how a legislative body goes about making its decision, it is indeed difficult for a judge to determine what is the will of that legislative body.

Reports and statements of chairmen of committees stand on a very different footing from that of general debates. These debates, it has been long established, are "expressive of the views and motives of individual members, and are not a safe guide, and hence may not be resorted to, in ascertaining the meaning

II United States v. St. Paul, M. \& M. R. Co., 247 U.S. 3 ro, $3^{8}$ Sup. Ct. 525,62 L.Ed. I 130 (IgI8).

${ }^{x 2}$ I 66 U.S. 290, I7 Sup. Ct. 540, 4I L.Ed. 1007 (1897).

${ }^{13}$ Where a bill has passed in one House and is amended in the other, if the House in which it first passed does not agree to the amendment, the bill is sent to a committee of conference where the differences are adjusted, and an agreed bill is reported back to each House. The statements made by the members of the conference committee in reporting or explaining the bill on the floor of either House are of great weight in the interpreting of a doubtful statute. This was recognized in United States v. Pfitsch, 256 U.S. 547, 4 I Sup. Ct. 569,65 L.Ed. xo84 (I921). See also, United States ex rel. Fazio v. Tod, 285 Fed. 847 (C.C.A. 2d I922).

is Omaha and Council Bluffs Street Ry. Co. v. Interstate Commerce Commission, $23^{\circ}$ U.S. 324, 33 Sup. Ct. 89o, 56 L.Ed. 324 (Ig12). 
and purpose of the lawmaking body." ${ }^{15}$ The reason for the rule was well stated by the court when it passed on the meaning of the Sherman Act. In his opinion Justice Peckham said:

The reason is that it is impossible to determine with certainty what construction was put upon an act by the members of the legislative body that passed it by resorting to the speeches of individual members thereof. Those who did not speak may not have agreed with those who did; and those who spoke might differ from each other. . . . ${ }^{16}$

The court may go even further than using the committee report to interpret doubtful language in the act. Where a particular interpretation of an act would lead to a result which seems contrary to the apparent purpose of the act, the court has resorted to the reports of a committee in order to determine whether or not the words of the act should be departed from in a particular case. The contract labor law, for example, applied to the importation of aliens under contract to labor. The question was whether a contract with an alien to become rector of a church was within the act. The court depended on an extract from the report of the Senate committee, recommending the passage of the bill, to show that the intent of the committee was that the act should not apply to a professional man. In its report the committee said that it considered the word "labor" would apply only to manual labor and rejected a suggested amendment to substitute the expression "manual labor" on the ground that it was unnecessary. This extract from the report, the court said, was "a circumstance throwing light upon the intent of the Congress."

Again, to determine the scope of the Federal Employers' Liability Act, the court in its opinion quoted from the report of a House committee, saying:

.... and the report of the Congressional committee having the bill in charge discloses, without any uncertainty, that it was intended to be very comprehensive, to withdraw all injuries to railroad employees in interstate commerce from the operation of varying state laws, and to apply to them a national law having a uniform application throughout all the states. ${ }^{\mathrm{P}}$

${ }^{{ }_{5}}$ Duplex Printing Press v. Deering, 254 U.S. 443, 475, 4I Sup. Ct. 172, 65 L.Ed. 349 (r920).

${ }^{36}$ United States v. Trans-Mo. Freight Assoc., I66 U.S. 290, 318, I7 Sup. Ct. 540, 4I L.Ed. 1007,1020 (I896).

See also: United States v. St. Paul, M. \& M. R. Co., 247 U.S. 3 IO, 38 Sup. Ct. 525, 62 L.Ed. $\Upsilon_{3} 30$ ( 1918 ); Lapina v. Williams, 232 U.S. 78,34 Sup. Ct. r96, 58 L.Ed. 515 (I9I4); Binns v. United States, r94 U.S. 486, 24 Sup. Ct. 816, 48 L.Ed. 1087 (r903). In McCaughan v. Hershey Chocolate Co., 283 U.S. 488, 493, 5I Sup. Ct. 5 ro, 75 L.Ed. 1 r8 3 (I930), the court said: "Nor do we think of significance the fact relied upon here and by the court below that statements inconsistent with the conclusion which we reach were made to committees of Congress or in discussions on the floor of the Senate by Senators who were not in charge of the bill. For reasons which need not be restated, such individual expressions are without weight in the interpretation of a statute."

${ }_{17}$ Church of the Holy Trinity v. United States, $x_{43}$ U.S. 457,464 , I2 Sup. Ct. 511 , 36 L.Ed. $226(\mathrm{r} 892)$.

${ }_{18}$ N.Y. C. R. Co. v. Winfield, 244 U.S. 147,37 Sup. Ct. 546, 6r L.Ed. 1045 , 1048 (1917).

See also: St. L., Iron Mountain \& So. Ry. v. Craft, 237 U.S. 648, 35 Sup. Ct. 704,59 L.Ed. Ir60 (Igr5); McLean v. United States, 226 U.S. 374, 33 Sup. Ct. I22, 57 L.Ed. 260 (I9I2); 
Another source of information resorted to in the construction of acts is the committee hearings, which are important in determining the factual situation with which the act was intended to deal. ${ }^{\mathrm{x}}$ Chief Justice Taft has explained the purpose for which hearings may be used, in his opinion sustaining the Packers' Act. ${ }^{20}$

In his statement setting forth the situation which confronted Congress, the object which the act was intended to accomplish and the evil with which Congress was dealing, he depended upon the hearings before the Committee to show how the trade in livestock was carried on and to show that there was a monopoly on the part of certain packing companies. The evidence printed in the hearings not only informed the court as to the general purpose of the act, thus aiding its interpretation, but was of importance in deciding the question of its constitutionality. In order to sustain the constitutionality of the regulation of a great trade as a reasonable exercise of the police power, the court must be persuaded that there was an evil and that the act might reasonably be expected to correct it without putting an undue burden on the business regulated. Furthermore, it had to be shown that the stockyards which were regulated by the act, were an instrument of interstate and foreign commerce so as to fall within the jurisdiction of the federal government. For these two purposes, the facts deduced by the court from the hearings, were of very great importance. ${ }^{2 \mathrm{~T}}$

Committee reports are now definitely a part of the equipment of the court for the interpretation of the meaning of statutes and for deciding their constitutionality. They are not decisive but they are persuasive. While there are no Supreme Court cases in which the opinion is based squarely on a report, a review of the decisions makes it apparent that the judges are turning to them in. creasingly for help in case of doubt. This tendency coincides with the improvement in the preparation of reports by committees and their counsel, so that the judges have instruments better fitted to their hands. Whether reports will be

Wm. Cramp \& Sons Ship \& Eng. Bldg. Co. v. Int. Curtis Marine Turbine Co., 246 U.S. 28 , $3^{8}$ Sup. Ct. 27 I, 62 L.Ed. 560 (I9I8); Knickerbocker Ice Co. v. Stewart, 253 U.S. 149, 40 Sup. Ct. 438,64 L.Ed. 834 (1920).

${ }^{39}$ Hearings were used generally to determine the situation with which Congress was dealing in adopting certain provisions of the Seamen's Act. O'Hara v. Luckenbach S.S. Co., 269 U.S. 364, 70 L.Ed. 3 II (I928). As statements made at the hearings often come from interested parties, they cannot be given greater weight than as a guide to the facts which were present in the minds of the committee members when they decided upon the action which they reported. McCaughan v. Hershey, ${ }_{28}$ U.S. 488 , 5 I Sup. Ct. 5 IO, 75 L.Ed. II 83 (I930).

${ }^{20}$ Stafford v. Wallace, $25^{8}$ U.S. 495, 53 3, $4^{2}$ Sup. Ct. 397, 66 L.Ed. 735, 740 (1921).

${ }^{21}$ There is a striking instance in the New York decisions of the effect of a finding of fact by a legislative committee, in this case a committee of inquiry on the constitutionality of a law. The New York Court of Appeals, in People v. Schweinler Press, 214 N.Y. 395 (Igr 5), abandoned the rule laid down in People v. Williams, 189 N.Y. I3I (rg08), holding finally that a statute forbidding night work for women was constitutional, and basing its reversal upon the report of a legislative committee of inquiry, whose fact findings revealed that the classification was reasonable. 